\title{
ANALISIS TOPOLOGI DAN POPULASI PENDUDUK PEMUKIMAN MISKIN MENGGUNAKAN TEKNOLOGI REMOTE SENSING
}

\author{
Endina Putri Purwandari dan Aniati Murni Arymurthy
}

Fakultas Ilmu Komputer, Universitas Indonesia, Kampus Baru UI Depok, Jawa Barat, 16424, Indonesia

E-mail: endina.putri@ui.ac.id

\begin{abstract}
Abstrak
Wilayah perkotaan di Indonesia memiliki karakteristik yang sama dengan wilayah perkotaan di negara-negara berkembang. Beberapa karakteristik tersebut seperti: (1) penurunan fungsi alam dengan berkurangnya ruang hijau atau vegetasi, (2) penumpukan bangunan beratap pada wilayah yang dekat dengan akses transportasi, industri dan pasar, (3) lokasi pemukiman pada zona yang berbahaya karena dekat dengan terminal, sepanjang aliran sungai, sepanjang jalur rel kereta api, dan tempat pembuangan sampah akhir. Keterkaitan antara nilai indeks kemiskinan dengan morfologi fisik dan vegetasi suatu wilayah dapat diketahui dengan pemanfaatan teknologi remote sensing (RS). Keakuratan analisis pemukiman miskin dengan teknologi RS bergantung pada kualitas citra satelit Very High Resolution (VHR) dan kelengkapan dataset Sistem Informasi Geografis (SIG). Teknologi Geospasial yang terintegrasi seperti RS, SIG, dan Global Positioning System (GPS) dapat berkontribusi secara interaktif dalam penilaian, pemahaman dan pemetaan untuk memecahkan masalah pemukiman penduduk yang kompleks di Indonesia.
\end{abstract}

Kata Kunci: pemukiman miskin, remote sensing, sistem informasi geografis

\begin{abstract}
Urban areas in Indonesia have the same characteristics with urban areas in developing countries. Some characteristics such as: (1) decreased of the function of nature with the reduced the number of natural green space or vegetation, (2) accumulation of roofed buildings in the area close to transportation access, industry and market, (3) the location of housing in the dangerous zone as close to the terminal, along the river side, along the railway lines, and the final waste disposal sites. The linkage between poverty index values with the physical morphology and vegetation of an area can be identified by the use of technology and remote sensing (RS). The accuracy of the analysis of poor housing with RS technology relies on the image quality of Very High Resolution (VHR) satellite and the completeness of the dataset Geographic Information Systems (GIS). Geo-spatial technologies are integrated as RS, GIS, and Global Positioning System (GPS) can contribute interactively in the assessment, understanding and mapping to solve the complex problem of residential in Indonesia.
\end{abstract}

Keywords: poor housing, remote sensing, geographic information systems

\section{Pendahuluan}

Pertambahan penduduk di dunia tidak hanya berasal dari kelahiran atau pertumbuhan penduduk alami, namun juga akibat pertumbuhan urbanisasi yang menyebabkan munculnya daerah pemukiman miskin dan padat. Setiap pusat pemukiman padat penduduk memiliki masalah degradasi fungsi lingkungan dengan skala yang berbeda.

Hal tersebut juga terjadi pada perkotaan besar di Indonesia. Tingginya populasi penduduk dalam mengubah pola konsumsi lahan, perkembangan industri yang tidak seimbang, ketidaksesuaian kepadatan transportasi, kurangnya pemenuhan kebutuhan pokok, penurunan sumber daya air serta flora dan fauna, dan infrastruktur lingkungan yang buruk selanjutnya menjadikan faktor utama penurunan kualitas lingkungan perkotaan [1].

Menurut perkiraan Millenium Development Goal (MDG) pada tahun 2020, sekitar 1.4 miliar manusia di dunia berada dalam kondisi miskin, tersebar di negara-negara berkembang. Indonesia merupakan negara berkembang dengan jumlah penduduk terbesar ketiga di dunia. Target kebijakan MDG di Indonesia hingga tahun 2015 adalah untuk mengurangi jumlah kemiskinan penduduk [2].

Hasil survei [3] yang dilakukan BPS pada bulan Maret 2009 menyebutkan bahwa jumlah penduduk miskin di Indonesia sebanyak 32.53 
juta jiwa atau 14.15 persen dari total populasi Indonesia. BPS juga melakukan Survei Sosial Ekonomi Sosial (SUSENAS) terhadap sampel rumah tangga untuk mengukur jumlah penduduk di bawah garis kemiskinan [3]. Hasilnya pada tahun 2007, sekitar 37.2 juta penduduk Indonesia berada di bawah garis kemiskinan. Namun situasi tersebut berbeda di setiap daerah. Penduduk yang hidup di perkotaan membutuhkan biaya yang lebih tinggi dibandingkan di pedesaan.

Berdasarkan survei tersebut perlu dilakukan program penanggulangan kemiskinan. Untuk meningkatkan efektivitas penanggulangan ini tidak dapat ditangani oleh satu sektor tertentu, tetapi harus lintas multi sektor yang melibatkan stakeholder terkait. Beberapa kebijakan yang diambil pemerintah untuk mengurangi jumlah kemiskinan yaitu dengan Program Nasional Pemberdayaan Masyarakat (PNPM) dan program Bantuan Langsung Tunai (BLT).

Umumnya peta sebaran penduduk miskin disusun secara tradisional dengan pendataan indeks penduduk secara manual di setiap wilayah administrasi. Peta tradisional ini memiliki kekurangan pada definisi kemiskinan yang tidak konsisten, jumlah yang tidak valid dan sulit melakukan perubahan tahunan atau per semester. Setiap terjadi perubahan maka perlu dilakukan pengambilan data ulang ke lapangan. Hal ini menyebabkan ketidaksesuaian informasi jumlah penduduk miskin di Indonesia yang dapat memengaruhi kebijakan pemerintah.

Untuk mengatasi permasalahan ini, beberapa negara seperti India, Filipina, dan Tanzania, telah melakukan pengembangan aplikasi untuk menganalisis topologi, morfologi dan estimasi jumlah populasi penduduk di pemukiman miskin dengan menggunakan indikator berdasarkan teknologi RS dan SIG. Dengan sensor citra satelit secara global dapat diperoleh gambaran observasi yang konsisten untuk memperkirakan jumlah populasi penduduk miskin. Peta sebaran kepadatan penduduk dan pemukiman miskin dapat menjadi alat yang penting untuk penanggulangan kemiskinan dan pengambilan kebijakan pemerintah.

Oleh karena itu, metode untuk analisis pemukiman penduduk masih diperlukan dengan menggunakan citra RS dengan resolusi tinggi untuk membangun dokumen pertumbuhan wilayah pemukiman secara interaktif. Untuk menilai dan mengevaluasi pola pemukiman miskin perlu perencanaan di tingkat berbeda dengan menggunakan informasi sosial ekonomi. Dengan demikian diperlukan pendekatan terintegrasi menggunakan citra satelit RS dan SIG yang diaplikasikan dengan data sosial-ekonomi pemerintah untuk menyelesaikan beberapa isu pemukiman penduduk miskin di Indonesia.

Kemiskinan merupakan dilema terbesar yang dihadapi penduduk di abad 21. Menurut perkiraan sekitar $42 \%$ atau 2.6 miliar manusia akan hidup dalam kemiskinan [1]. Sebenarnya konteks kemiskinan tidak hanya diukur dari penghasilan (income poverty), tetapi juga kondisi rumah yang buruk dan kumuh, serta kekurangan bahan kebutuhan pokok, sehingga terkadang kemiskinan "memiliki banyak dimensi". Bahkan jumlah penduduk dan pemukiman miskin di Indonesia diperkirakan akan bertambah pada tahun 2010 .

UN-HABITAT [4] menyatakan sekitar $60 \%$ penduduk Indonesia tinggal di pemukiman miskin pada wilayah perkotaan. Pemukiman miskin adalah pemukiman padat dengan karakteristik penduduk mengalami kekurangan untuk memenuhi kebutuhan dasar dan rumah [4]. Motivasi munculnya pemukiman miskin adalah ketersediaan lapangan pekerjaan, kemudahan lokasi pasar dan pusat perbelanjaan untuk pemenuhan kebutuhan hidup, kedekatan dengan wilayah industri dan komersial, akses layanan publik, akses jaringan transportasi umum dan ketersediaan air.

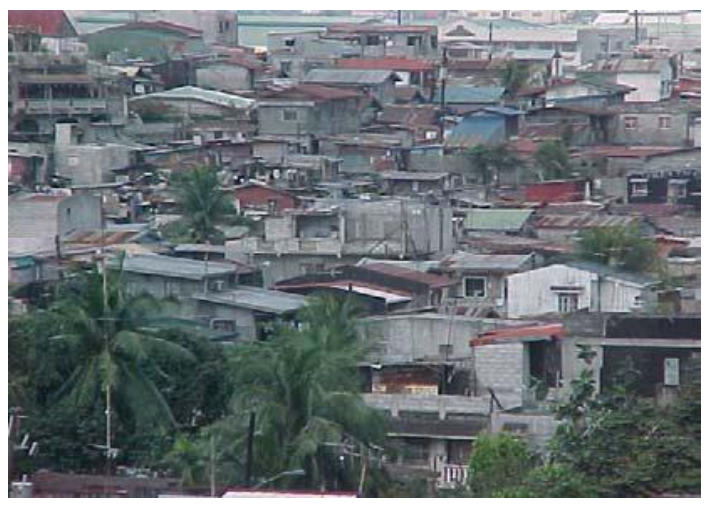

Gambar 1. Bentuk pemukiman miskin dan padat [5].

Sebagai data penelitian dengan menggunakan bentuk indikator spasial pada wilayah miskin yang diekstraksi dari citra RS. Indikator spasial digunakan untuk memahami heterogenitas wilayah pemukiman miskin. Indikator tersebut digolongkan berdasarkan karakteristik tertentu seperti kepadatan roof coverage, sedikitnya jaringan jalan, dan bentuk pemukiman yang tidak teratur (lihat gambar 1).

Karakteristik lokasi-lokasi berkembangnya pemukiman miskin pada data spasial antara lain pertama, pola tata ruang di mana rencana pola tata ruang wilayah pembangunan lahan dan alokasi pemukiman yang kurang baik, tidak ada ruang terbuka dan jalan yang menimbulkan kecenderungan bentuk dan ukuran yang tidak 
teratur. Sebaliknya alokasi perumahan yang teratur memiliki ruang terbuka yang lebih menonjol.

Kedua, struktur rumah di mana perumahan padat cenderung memiliki struktur ukuran yang lebih kecil dan bersebelahan atau berhimpitan. Ketiga, batas rumah di mana pemukiman rumah yang spontan tanpa perencanaan memiliki bentuk batasan poligon yang tidak teratur. Keempat, cluster dan penyebaran pemukiman di mana tanpa perencanaan yang jelas menyebabkan ketidakseimbangan, tidak meratanya cluster populasi padat di satu sisi dan populasi yang jarang di sisi lainnya, tidak ada wilayah vegetasi dan ruang wilayah publik yang cukup.

Kelima, bentuk reflektance atau radiasi di mana umumnya wilayah pemukiman informal memiliki bentuk radiasi yang berbeda karena degradasi alam, ukuran bangunan dan sifat material bangunan yang mudah rusak sehingga terlihat lebih gelap. Keenam, atribut lokasi di mana biasanya pemukiman padat terletak di perkotaan, dekat wilayah komersial dan industri sebagai daya tarik utama urbanisasi serta mencari tempat tinggal yang dekat dengan tempat kerja. Selain itu, pemukiman ini sering ditemukan pada zona berbahaya seperti sekitar aliran sungai, sepanjang rel kereta api, di bawah jembatan layang, dan dekat tempat pembuangan sampah.

\section{Metodologi}

Teknologi RS mengembangkan metode untuk identifikasi pemukiman miskin berdasarkan citra VHR dan dataset tambahan seperti sensus serta data SIG terkait dengan infrastruktur dan layanan penduduk. Beberapa penelitian telah menganalisis pembagian bentuk topologi dan morfologi pemukiman miskin berdasarkan karakteristik data spasial dan citra RS, sehingga dapat mengestimasi jumlah penduduk miskin.

Sliuzas dan Kuffer [5] melakukan penelitian heterogenitas spasial pada pemukiman miskin menggunakan teknologi RS berdasarkan indikator spasial seperti kepadatan roof coverage, ketersediaan jaringan jalan, dan bentuk pemukiman yang tidak teratur. Identifikasi dilakukan dengan memeriksa variabel morfologi dan variabel lokasi spasial. Proses ekstraksi informasi secara otomatis dengan klasifikasi supervised maximum likelihood [5]. Berdasarkan indikator tersebut heterogenitas dari lingkungan pemukiman miskin dapat diidentifikasi dalam tipe berbeda.

Sedangkan May Celine [6] menganalisis citra VHR untuk mendeteksi bangunan, estimasi kemungkinan bencana alam dan membangun dasar statistik pengembangan instrumen. Pada pembahasan [6] Urban Poverty Morphology (UPM) diaplikasikan dalam tiga tahap. Tahap UPM I mendesain algoritma dan metode ekstraksi untuk peta perubahan lahan, UPM II mengembangkan peta relokasi pemukiman miskin di perkotaan, dan UPM III untuk pemetaan kemiskinan multi-temporal dalam skala nasional, regional dan lokal. Metode klasifikasi yang digunakan adalah Bayesian atau klasifikasi maksimum likelihood.

Aminipouri et al. [7] mengembangkan metode analisis berorientasi objek pada citra VHR dan data SIG, untuk menghitung jumlah populasi penduduk yang tinggal di pemukiman miskin dan angka Roof Area per Person (RApP). Pendekatan dengan memerhatikan indikator sosial untuk mengestimasi variabel karakteristik fisik bangunan, akses jalan, dan ruang hijau. Proses ekstraksi citra RS dengan chessboard segmentation dan multiresolution segmentation. Hasil segmentasi diklasifikasi dengan fuzzy dan nearest neighborhood.

Berdasarkan review penelitian yang telah dilakukan, langkah-langkah penelitian dan pengembangan sistem analisis pemukiman miskin dengan RS untuk Indonesia dapat digambarkan sebagai diagram alur pada gambar 2. Langkahlangkah tersebut diawali dengan studi literatur yang memunculkan permasalahan utama, tujuan penelitian dan pengembangan permasalahan. Tujuan penelitian adalah untuk mengetahui ekstraksi bangunan, klasifikasi topologi dan menghitung estimasi populasi penduduk yang tinggal pada pemukiman miskin. Untuk mencapai tujuan tersebut membutuhkan data masukan berupa data citra RS yang menghasilkan analisis data spasial citra. Selanjutnya citra hasil pemetaan wilayah akan dianalisis. Berdasarkan analisis dan pembahasan dapat ditarik kesimpulan dan saran pengembangan lebih lanjut.

Analisis bentuk heterogenitas wilayah pemukiman miskin dengan indikator remote sensing. Sliuzas dan Kuffer [5] membahas identifikasi lokasi pemukiman miskin pada kota megapolitan New Delhi di India, dengan menggunakan data RS untuk mendapatkan profil kemiskinan secara spasial dan mengambil kebijakan dalam mengurangi kemiskinan dan urbanisasi. Metodologi ekstraksi heterogenitas spasial kemiskinan terbagi dalam dua tahap utama, yaitu interpretasi visual terhadap variabel spasial dari citra Ikonos dengan ekstraksi informasi otomatis, dan klasifikasi supervised maximum likelihood. 


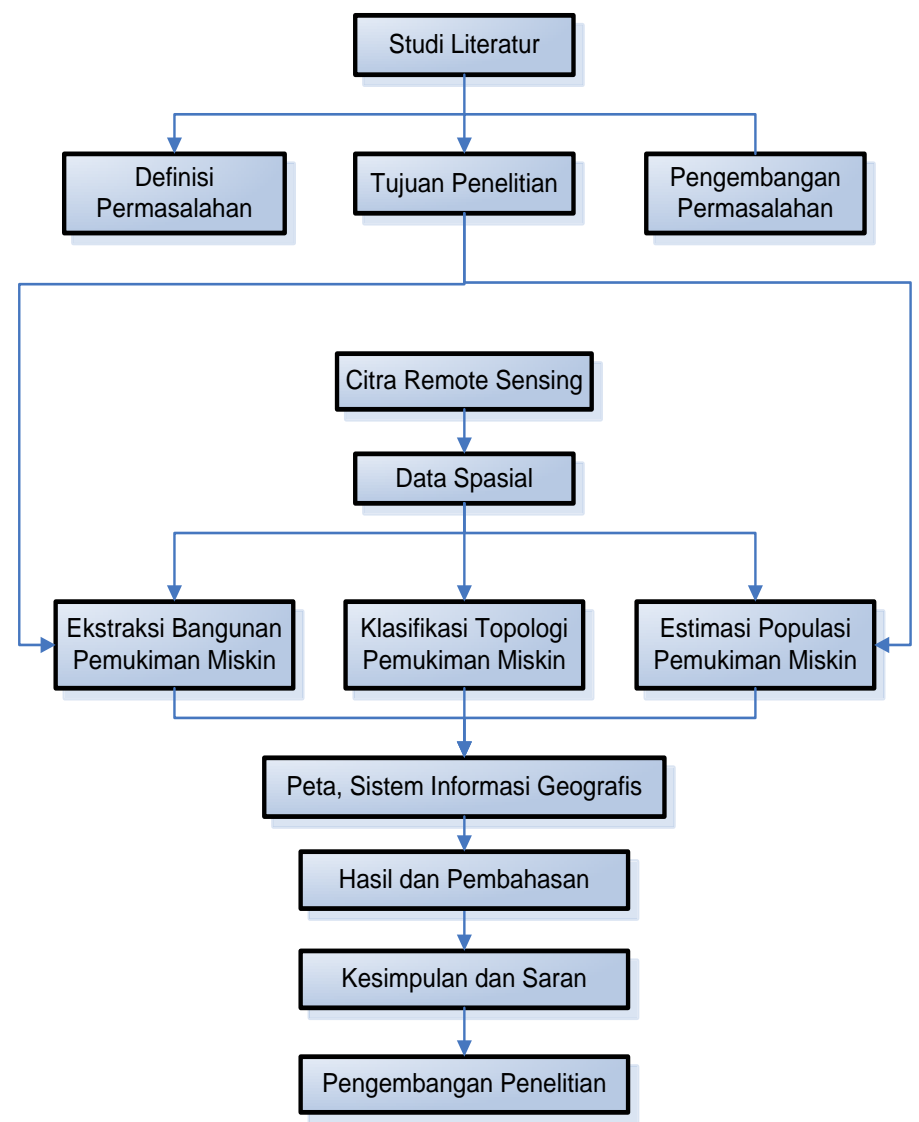

Gambar 2. Diagram alur masukan, proses, dan keluaran.

Tahapan interpretasi dengan variabel spasial mencakup: (1) variabel morfologi pemukiman urban dengan indikator struktur layout bangunan tidak teratur dengan jalan akses yang sempit, kepadatan bangunan yang melebihi $80 \%$ dari luas wilayah, ukuran bangunan yang kecil, dan (2) variabel lokasi kesesuaian tempat tinggal yang dekat dengan lokasi berbahaya dan rawan bencana alam, serta jarak dengan pusat kota yang dekat. Selanjutnya tahap klasifikasi dilakukan dengan menggunakan lima kategori objek, yaitu air, tanah, vegetasi hijau, bangunan, dan jalan.

Topologi pemukiman penduduk miskin terbagi menjadi dua bentuk utama yaitu bangunan informal dan formal. Bangunan informal memiliki pola struktur bangunan dan jalan yang tidak teratur, ruang hijau yang sedikit (lihat gambar 3.a). Bangunan formal merupakan pemukiman padat penduduk yang dengan struktur bangunan dan bentuk jalan yang teratur (lihat gambar 3.b).

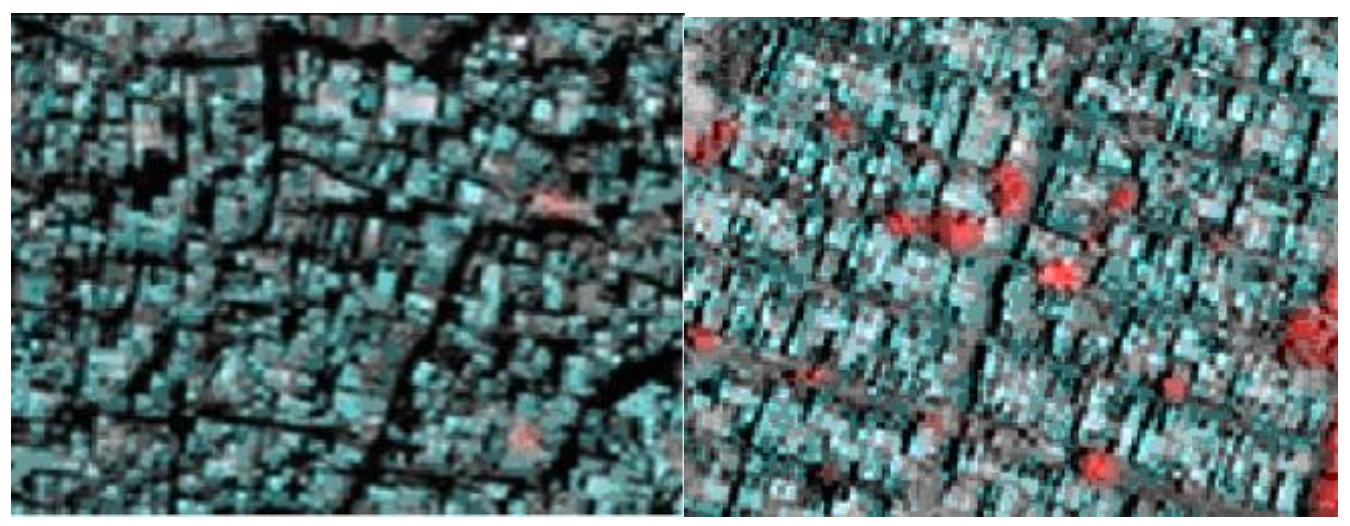

(a)

(b)

Gambar 3. Topologi pemukiman miskin (a) informal dan (b) formal [5]. 
Konsep klasifikasi struktur karakteristik Urban Structure Types (UST) menjadi landasan yang penting dalam penelitian. Karakteristik UST dinyatakan dengan identifikasi kelas yang berbeda sesuai tipe bangunan (seperti perbedaan bentuk bangunan, industri, infrastruktur), kelas bentuk jalan (seperti jalan gang, jalan utama, lahan parkir), dan kelas ruang terbuka (seperti taman, tempat olahraga umum) [8]. Pola vegetasi dan ruang terbuka penduduk dianalisis sebagai elemen positif pada struktur lingkungan penduduk termasuk keseimbangan ekologi seperti biodiversity, produksi oksigen, dan fungsi sosial untuk tujuan rekreasi dan sosialisasi penduduk. Udara yang buruk menjadi sumber potensi penyakit sebagai struktur elemen negatif penduduk. Pertumbuhan populasi yang tinggi di perkotaan mengakibatkan beragam dampak positif dan negatif. Sliuzas dan Kuffer [5] membedakan bentuk wilayah pemukiman miskin kepadatan tinggi dengan kepadatan menengah.

Analisis morfologi pemukiman miskin pada penduduk urban. Pembahasan May Celine menekankan pada aplikasi SIG dan RS untuk memetakan wilayah miskin dalam skala morfologi yang beragam [6]. Aplikasi tersebut mencakup analisis wilayah lokasi untuk prioritas rehabilitasi dan relokasi penduduk miskin di kota ke daerah lain di kota Metro-Manila, Filipina [6]. Tahapan dalam Urban Poverty Morphology (UPM) terbagi menjadi: UPM I, mendesain algoritma dan metode ekstraksi perubahan lahan. Tujuannya untuk memahami dimensi spasial kemiskinan pada perkotaan dan menentukan hal penarik sosialekonomi utama bagi penduduk urban ke kota. Hasil penelitian UPM I diperoleh lokasi dan konteks pemukiman miskin dalam bentuk SIG sebagai alat pemetaan dan analisis spasial kemiskinan. UPM I menunjukkan deteksi wilayah pemukiman informal dan mengintegrasikan wilayah miskin perkotaan dalam lingkungan yang lebih baik.

Prosedur pemrosesan dan klasifikasi pada UPM I yaitu pertama pre-processing dan image registration, bertujuan untuk memperbaiki citra asli. Kedua, image processing terlihat pada gambar 4, bertujuan untuk meningkatkan variabilitas fitur parameter yang meliputi, Normalized Difference Vegetation Index (NDVI) = (XSNIR-XSR)/ (XSNIR+XSR), Index of Brilliance $(\mathrm{IB})=$ Sqrt [(XSR)2+(XSNIR $) 2]$, Panchromatic High - Boost $=$ (sejumlah band)original + high pass, Modified Index of Sedimentation $(\mathrm{MIS})=$ Sqrt $[(\mathrm{Pan}\{$ high - boost $\}) 2+(\mathrm{XSG}) 2], \quad$ Principal Components Analysis (PC1: XSNIR, XSG).

Prosedur yang ketiga yaitu klasifikasi citra dilakukan dengan metode maximum likelihood yakni mengelompokkan kelas objek menjadi wilayah: pemukiman kepadatan tinggi, pemukiman kepadatan rendah, air, industri, komersial, ruang terbuka, dan vegetasi. Prosedur keempat filtering, suatu filter juga digunakan untuk memperbaiki kualitas respon spektral dengan tujuan meningkatkan proses identifikasi. Prosedur kelima yaitu accuracy assessment, penilaian keakuratan klasifikasi pola bangunan citra RGB = (XSNIR, XSR, XSG) dibandingkan dengan citra RGBI = (NVDI, IB, MIS, Pan $)$. Prosedur keenam yaitu pemetaan, hasil peta direpresentasikan sebagai peta citra raster yang menunjukkan wilayah dan kuantifikasi penggunaan lahan. Prosedur ketujuh, integrasi dilakukan dengan foto udara. Prosedur kedelapan penurunan layer SIG menggunakan foto udara sebagai background informasi tematik digunakan untuk digitasi jalan, pemukiman informal, bangunan, aliran air, dan wilayah industri.

Tahapan yang kedua yaitu UPM II, melakukan penilaian strategis lingkungan pada pemukiman miskin. Penilaian ini untuk menentukan resiko dan potensi kerentanan masyarakat. Hasil penilaian menunjukkan bahwa wilayah relokasi tidak sesuai untuk pemukiman karena resiko bencana alam yang tinggi, ketiadaan sumber kehidupan dan transportasi umum. Tahapan ketiga yaitu UPM III, mengembangkan peta kemiskinan multi-temporal dalam tiga skala (nasional, regional dan lokal) dengan menentukan distribusi dan pertumbuhan spasial. Hasil menunjukkan pemukiman miskin di Manila semakin luas dan padat. UPM III juga melakukan analisis migrasi dan distribusi spasial terhadap pemukiman informal. Pemrosessan citra RS pada UPM III dimulai dengan citra masukan RGB: $\mathrm{R}=$ Red, $\mathrm{G}=$ Green, dan $\mathrm{B}=$ Blue, selanjutnya menggunakan tiga algoritma, yaitu, Natural color algorithm, di mana RGB: $\mathrm{R}=$ Red, $\mathrm{G}=\left(\right.$ Green $\left.^{*} 3+\mathrm{NIR}\right) / 4$, dan $\mathrm{B}=$ Blue, Normalized Index of Vegetation (NDVI), Index of Brilliance (IB), Index of Sedimentation (IS) Algorithm, di mana RGB: $\mathrm{R}=(\mathrm{NIR}-\mathrm{Red}) /(\mathrm{NIR}+\mathrm{Red})$, $\mathrm{G}=($ Red $+\mathrm{NIR}) \mathrm{IB}$, dan $\mathrm{B}=($ Red + Green $) \mathrm{IS}$, Hue Saturation Intensity (HIS) Algorithm.

Lokasi pemukiman miskin selanjutnya ditumpangtindihkan pada ketiga dataset, dan proses interpretasi dilakukan dengan melakukan deliniasi batas-batas pemukiman miskin. 


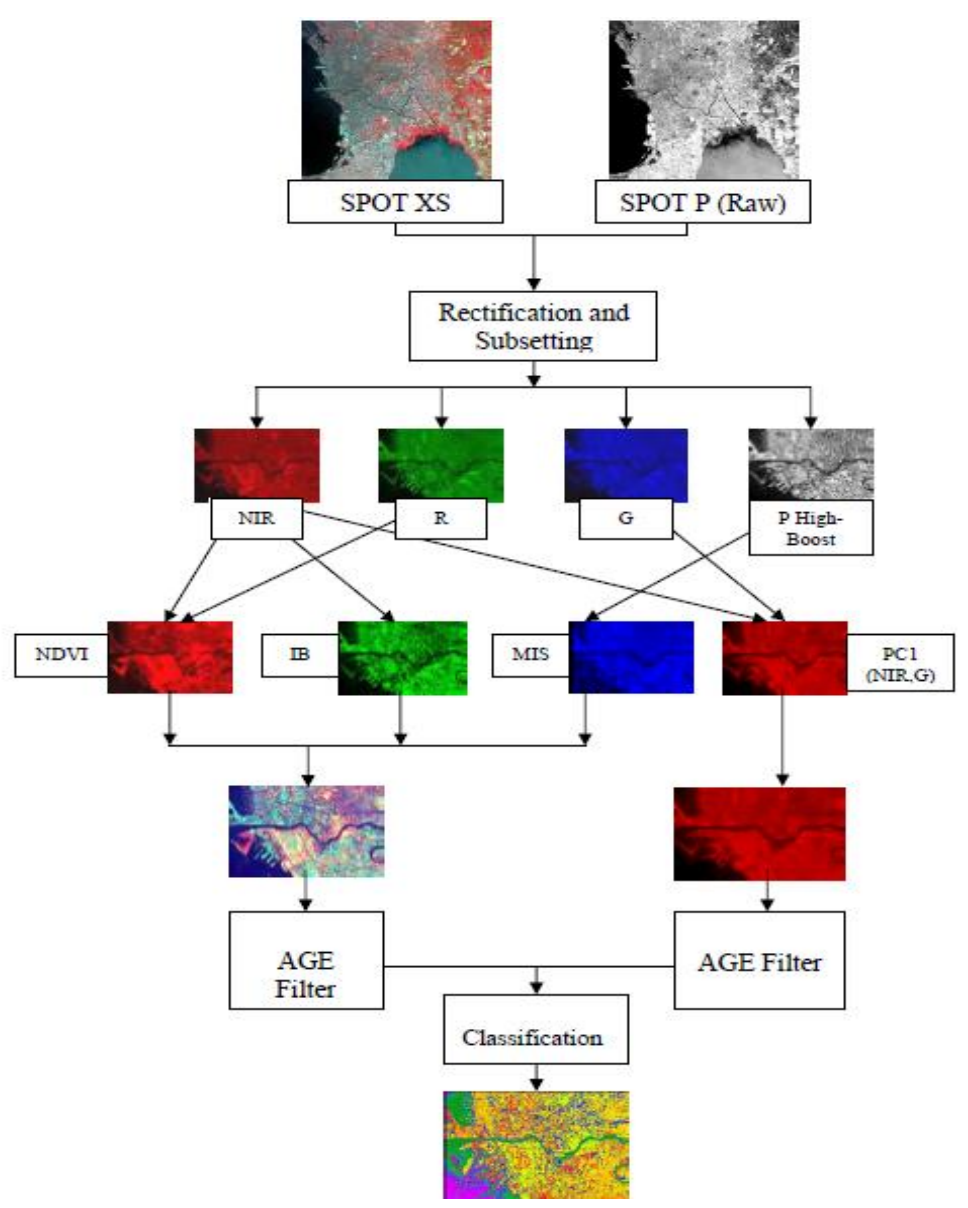

Gambar 4. Proses kerja UPM I [6].

Analisis berorientasi objek untuk estimasi populasi pemukiman miskin. Aminipouri et al. [7] membahas studi kasus pada wilayah Dar-EsSalaam di negara Tanzania, Afrika. Tujuannya adalah untuk melakukan proses klasifikasi, segmentasi bangunan rumah dan estimasi jumlah populasi pemukiman miskin, serta inventori bangunan. Data yang digunakan meliputi citra foto udara dan citra satelit VHR orthopotos dengan ukuran 0.6 meter piksel yang membantu ekstraksi informasi wilayah pemukiman miskin berdasarkan teknik berorientasi objek. Dalam analisis citra berorientasi objek menganggap citra sebagai sekumpulan objek daripada piksel. Kelebihan analisis ini membentuk objek secara hierarki dengan segmentasi citra dan kombinasi segmentasi multi-skala dengan analisis properti spasial, spektral, dan kontekstual dari segmen ekstraksi pada skala spasial berbeda.

Klasifikasi dan segmentasi objek bangunan dilakukan pada tiga wilayah di Dae-Es-Salaam Tanzania, yaitu daerah Charambe, Manzese dan Tandale dengan karakteristik pemukiman miskin yang berbeda-beda. Wilayah Manzase dan Tandale memiliki bentuk perumahan yang lebih rapat dengan struktur yang tidak teratur, serta ruang hijau yang sedikit (lokasi lebih dekat dengan pusat kota). Sedangkan wilayah Charambe memiliki bentuk pemukiman penduduk yang lebih jarang dan struktur lebih teratur, ruang hijau yang lebih banyak (lokasi lebih dekat ke pinggiran kota).

Proses segmentasi citra adalah operasi untuk membuat objek citra atau menambahkan morfologi objek berdasarkan kriteria yang diberikan. Strategi segmentasi dilakukan secara top-down atau bottom-up. Teknik segmentasi dapat menggunakan segmentasi chessboard dan multiresolution. Segmentasi chessboard adalah segmentasi top-down dengan memotong objek citra menjadi citra lebih kecil. Teknik ini membagi lahan dan mereduksi jumlah unit untuk klasifikasi citra, serta mengurangi waktu pemrosesan. Segmentasi multiresolution menggunakan strategi bottom-up, di mana objek lebih kecil digabungkan menjadi objek lebih besar dengan memilih bobot parameter skala, warna dan ukuran (bobot mulai dari 0 sampai 1). Semakin tinggi nilai parameter maka semakin besar ukuran objek. Semua parameter segmentasi multiresolusi ditentukan dengan trial dan error melalui eksperimen sistematis. 
Klasifikasi fuzzy membership functions digunakan untuk menggambarkan dan mengelompokkan objek di kelas berbeda. Rasio band Red dan Blue digunakan untuk ekstraksi atap dan band Green untuk ekstraksi wilayah vegetasi hijau; dan rasio panjang/lebar bangunan untuk ekstraksi bayangan bangunan. Hasil dari klasifikasi fuzzy masih terjadi kesalahan identifikasi kelas, sehingga perlu dilakukan klasifikasi Nearest Neighborhood (NN) untuk memperbaiki ekstraksi yang salah. Klasifikasi NN menggunakan sampel dari kelas berbeda untuk menentukan nilai keanggotaan antara 0 dan 1 . Nilai keanggotaan 1 memiliki probabilitas tinggi diidentifikasikan dalam kelas yang sama. Hasil klasifikasi dapat dilihat pada gambar 5 .

Penilaian keakuratan identifikasi dilakukan dengan menghitung building extraction rate, roof area coverage, total estimated population dan mean relative error. Building Extraction Rate (BER) bangunan dilakukan dengan membagi jumlah bangunan yang berhasil diekstraksi dengan jumlah referensi poligon bangunan. Roof Area Coverage (RAC) merupakan luas wilayah bangunan terekstraksi dibagi dengan luas wilayah referensi poligon. Total Estimated Population (TEP) dimodelkan sebagai hasil kali antara bangunan yang terekstraksi dengan jumlah Reference Area per Person (RApP). RApP merupakan data jumlah orang yang tinggal di pemukiman miskin yang diperoleh dari survei langsung ditingkat RT. Evaluasi estimasi populasi pemukiman miskin dilakukan dengan menghitung Mean Relative Error (MRE) yaitu jumlah total estimasi populasi (TEP) dibagi jumlah total referensi populasi.

Menurut Aminipouri et al. [7] ada bangunan yang tidak dapat terekstraksi karena tertutupi pohon atau memiliki material roof yang berbeda. Hasil penilaian keakuratan roof coverage untuk bangunan yang berhasil diekstraksi pada wilayah Tandale adalah $82.6 \%$, Manzese $90.2 \%$ dan Charambe $97.1 \%$. Perhitungan mean relative error di ketiga wilayah adalah $25.7 \%$, artinya terdapat perbedaan sebesar $25.7 \%$ antara data asli referensi dengan data hasil estimasi penelitian. Perbedaan tersebut menunjukkan bahwa sebesar $25.7 \%$ bangunan yang tidak berhasil diekstraksi dengan sistem yang diusulkan.

\section{Hasil dan Pembahasan}

Pengumpulan dan pengolahan data. Secara umum bentuk data dalam SIG dapat dibedakan menjadi dua macam yaitu data raster dan data vektor. Data raster adalah data di mana objek disajikan secara sekuensial pada kolom dan baris dalam bentuk piksel, umumnya berbentuk data citra satelit yang sudah siap dibaca oleh komputer. Data vektor adalah struktur data yang berbasis pada sistem koordinat untuk menyajikan fitur peta. Data vektor biasanya diperoleh dengan alat digitasi.

Citra input dalam penelitian menggunakan citra hasil RS resolusi tinggi VHR untuk mengembangkan pendekatan metodologi dalam mengombinasikan indikator indeks kemiskinan. Citra VHR dibutuhkan untuk meningkatkan detil informasi pemetaan pemukiman miskin. Selain itu, citra foto udara juga digunakan sebagai input SIG.

Semakin banyak sumber data input citra satelit, maka semakin tinggi keakuratan ekstraksi data yang dicapai, karena setiap citra satelit resolusi tinggi tersebut memiliki karakteristik berbeda yang saling melengkapi. Keberagaman citra satelit tersebut juga memperkaya fitur analisis RS dengan band yang berbeda, seperti band Red, Green, Blue, dan NIR.

Software yang digunakan adalah ESRI ArcGIS dan Microsoft Excel. Esri ArcGIS untuk digitasi wilayah peta, manajemen dataset dan pemrosesan awal data raster dan data vektor citra. Sedangkan Microsoft Excel untuk analisis data statistik.
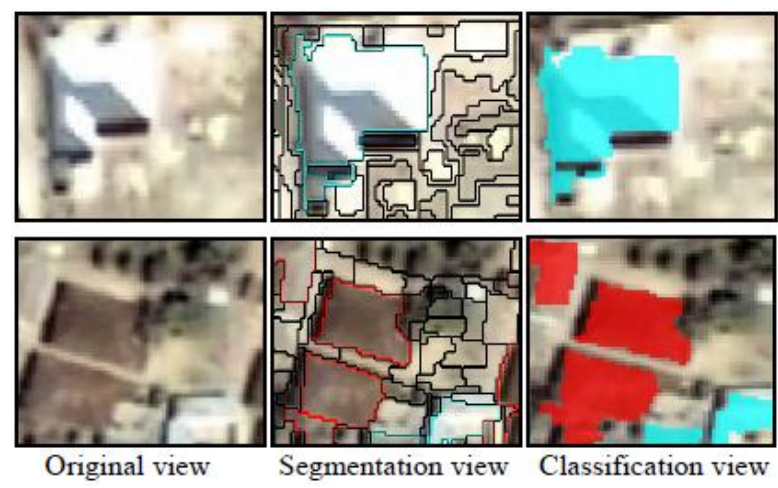

Gambar 5. Hasil klasifikasi Nearest Neighborhood [7]. 
Analisis pengembangan sistem profil pemukiman miskin. Peta sebaran pemukiman miskin sangat dibutuhkan untuk mendapatkan gambaran mengenai penduduk miskin yang lebih baik. Pemetaan kemiskinan didefinisikan sebagai analisis dan representasi spasial dari indikator kehidupan manusia. Peta tersebut diproduksi dalam skala berbeda berdasarkan citra RS.

RS atau penginderaan jarak jauh adalah cara pemantauan tentang sifat dan kondisi suatu objek atau fenomena alam di permukaan bumi untuk mendapatkan informasi tentang objek itu sendiri ataupun sekitarnya tanpa kontak langsung dengan suatu alat sensor. RS memiliki kemampuan dalam pemantauan dan mendapatkan informasi. Informasi tersebut merupakan kenampakan objek yang terlihat melalui foto udara atau citra satelit.

Informasi objek memiliki karakteristik dalam memantulkan, menyerap, memancarkan energi gelombang elektromagnetik sehingga pancaran yang diterima sensor digunakan sebagai ciri pengenalan objek, daerah atau fenomena yang dikaji [9]. Keterkaitan antara teknologi SIG dan RS adalah bahwa informasi yang diturunkan dari analisis RS selanjutnya diintegrasikan dengan basis data SIG. Setiap pengolahan masukan data yang berasal dari RS ke SIG melibatkan intervensi manusia dalam analisisnya.

Berdasarkan pembahasan penelitian sebelumnya dapat diusulkan metode untuk analisis topologi dan populasi penduduk di pemukiman miskin dengan citra remote sensing. Data-data variabel spasial untuk menggambarkan wilayah pemukiman miskin secara fisik meliputi morfologi dan lokasi.

Morfologi terdiri dari beberapa hal, yakni pertama, struktur yang pengukuran variabelnya dilakukan dengan memeriksa keberadaan akses jalan dengan lebar jalan kurang dari 3 meter, tidak ada pola yang terencana, bentuk poligon rumah yang tidak sama, dan keberadaan wilayah ruang hijau yang sedikit. Kedua, kepadatan bangunan, yang diukur dengan luas kepadatan bangunan dan roof coverage yang lebih dari $80 \%$ dari luas wilayah tersebut. Ketiga, ukuran bangunan, biasanya pemukiman miskin memiliki ukuran bangunan yang kecil dan rapat tanpa ada batasbatas rumah yang jelas, karena pemukiman dibangun secara spontan. Keempat, reflektance atau radiasi, wilayah pemukiman miskin dan kumuh memiliki bentuk radiasi yang berbeda dengan sekitarnya karena degradasi fungsi alam. Reflektance diukur dengan sifat material bangunan yang mudah rusak sehingga memantulkan cahaya lebih gelap. Material bangunan pemukiman miskin berupa sisa-sisa material bangunan bekas dan atap yang lebih gelap.
Lokasi terdiri dari kesesuaian tempat dan jarak dengan kota. Kesesuaian tempat merupakan variabel yang diukur dengan memeriksa posisi pemukiman. Biasanya pemukiman miskin dan kumuh di perkotaan terletak dekat dengan zona berbahaya, seperti dekat dengan jalan raya dan wilayah industri, di sekitar rel kereta api, di sepanjang aliran sungai, dan di sekitar tempat pembuangan sampah akhir. Jarak dengan kota, di mana pengukuran variabel ini dilakukan dengan menghitung jarak terhadap pemukiman dengan pusat kota. Posisi pemukiman miskin terletak sekitar kurang dari $10 \mathrm{~km}$ dari pusat kota.

Berdasarkan data variabel spasial tersebut di atas, pembagian bentuk topologi bangunan pada pemukiman miskin menjadi pemukiman padat informal, pemukiman kumuh informal, pemukiman padat formal.

Pemukiman padat informal, memiliki indikator data spasial yaitu pola struktur bangunan tidak teratur, tidak ada akses jalan yang lebarnya lebih dari 3 meter, tidak ada ruang hijau, kepadatan bangunan mencapai $80 \%$ dari luas wilayah, ukuran bangunan yang kecil. Pemukiman kumuh informal, memiliki indikator data spasial yaitu pola struktur bangunan tidak teratur, tidak ada akses jalan yang lebarnya lebih dari 3 meter, tidak ada ruang hijau, kepadatan bangunan mencapai $90 \%$ dari luas wilayah, ukuran bangunan yang kecil, dan lokasi pemukiman rawan bencana dan berbahaya seperti di sekitar rel kereta api, jalan raya, dan sungai. Pemukiman padat formal, merupakan pemukiman padat penduduk yang teratur dengan indikator data spasial yaitu lebar jalan yang lebih 3 meter, adanya ruang hijau, kepadatan bangunan mencapai $80 \%$ dari luas wilayah, ukuran bangunan yang kecil, dan jarak dengan pusat kota lebih dari $10 \mathrm{~km}$.

Langkah pertama dalam membangun peta pemukiman miskin adalah menentukan wilayah administratif sebagai sampel dan indikator kemiskinan yang dapat menjadi karakteristik dasar peta. Hal tersebut penting untuk pengambilan kebijakan dan keputusan. Data tersebut dimasukkan ke dalam sistem SIG untuk pemetaan statistik berdasarkan hasil basis data spasial untuk indikator kemiskinan. Pemetaan statistik multi-temporal menunjukkan perubahan yang terjadi dalam periode tertentu. Usulan diagram langkah-langkah analisis citra RS untuk pemukiman miskin, dapat dilihat pada gambar 6 .

Sintesa langkah-langkah analisis citra RS untuk deteksi pemukiman miskin antara lain multisensor citra VHR, pre-processing untuk perbaikan citra, ground truth, analisis data spasial dan data atribut, segmentasi citra, klasifikasi citra untuk ekstraksi objek. Pada multisensor citra 
VHR, citra yang digunakan dapat berupa citra Ikonos, citra SPOT P (pankromatik), XS (multispektral) yang merupakan citra VHR.

Data masukan penelitian menentukan kualitas hasil ekstraksi dan klasifikasi pemukiman miskin. Semakin banyak sumber data masukan citra satelit, maka semakin tinggi keakuratan ekstraksi data yang dicapai, karena setiap citra satelit resolusi tinggi tersebut memiliki karakteristik berbeda dan saling melengkapi. Keberagaman citra satelit tersebut, memerkaya fitur analisis data RS dengan berbagai band, seperti band Red, Green, Blue, dan NIR.

Pada pre-processing untuk perbaikan citra merupakan koreksi geometri untuk memerbaiki kesalahan posisi objek-objek yang terekam pada citra karena distorsi yang bersifat geometri. Dalam proses perbaikan citra juga dilakukan pemotongan citra lokasi penelitian untuk memudahkan dalam analisis data yang akan diklasifikasi. Pemotongan ini bertujuan untuk membatasi luasan wilayah citra dengan menggunakan Area Of Interest (AOI).

Ground truth atau pengecekan lapangan merupakan kegiatan untuk pengambilan titik di lapangan dalam membantu proses klasifikasi dan meningkatkan kualitas dan akurasi hasil analisis citra. Ground truth dilakukan dengan menggunakan alat bantu berupa Global Positioning System (GPS) untuk pengambilan titik di lapangan lebih baik sebanyak mungkin dan merata sehingga dapat mewakili setiap kelas objek. Selain itu, juga digunakan citra foto udara yang dipakai sebagai data tambahan dalam dataset citra dan pengujian ground truth.

Pemeriksaan ground truth adalah survei yang dibutuhkan sebagai landasan dasar untuk memeriksa secara akurat hasil peta kemiskinan yang diperoleh. Peta merefleksikan statistik spasial-temporal yang dapat digunakan untuk menunjukkan solusi permasalahan sosial ekonomi dan lingkungan.

Data masukan ke sistem terdiri dari data spasial dan data atribut. Data spasial merupakan data yang bersifat keruangan dari pengolahan citra RS VHR. Sedangkan data atribut adalah data yang berbentuk angka seperti data kependudukan, parameter vegetasi dan parameter sosial ekonomi masyarakat.

Beberapa data dan variabel parameter sebagai karakteristik pemukiman padat penduduk perlu digunakan untuk meningkatkan akurasi. Variabel-variabel tersebut antara lain adalah indikator struktur bangunan, material atap, ukuran bangunan, bentuk akses jalan, vegetasi ruang publik dan lokasi pemukiman [5]. Sedangkan parameter untuk pemrosesan ekstraksi perubahan lahan pemukiman adalah Normalized Difference
Vegetation Index (NDVI), Index of Brilliance (IB), Panchromatic High-Boost, Modified Index of Sedimentation (MIS) dan Principal Components Analysis (PCA) [6].

Tahapan segmentasi citra menggunakan strategi yang diusulkan Aminipouri [7] yaitu dengan strategi bottom-up dan top-down. Strategi tersebut mengaplikasikan analisis berorientasi objek, dengan menganggap citra sebagai sekumpulan objek daripada piksel. Kelebihan analisis ini memiliki segmentasi citra dengan bentuk objek yang hierarki, mengorelasikan objek nyata dan objek citra, dan mengombinasikan segmentasi multi skala dengan analisis properti spasial, spektral, dan kontekstual pada skala spasial berbeda.

Pada tahap klasifikasi citra untuk ekstraksi objek, digunakan dua metode klasifikasi yaitu klasifikasi fuzzy dan Nearest Neighborhood yang mengadaptasi proses analisis berorientasi objek pada [7]. Ekstraksi objek pada citra VHR terbagi menjadi ekstraksi building roof, wilayah vegetasi dan bayangan. Proses ekstraksi building roof dilakukan dengan memerhatikan kontribusi kanal dari band Blue dan Red. Untuk ekstraksi wilayah vegetasi dengan menghitung kontribusi kanal band Green. Sedangkan ekstraksi bayangan dihitung dengan rasio perbandingan panjang dan lebar bangunan.

Sintesa langkah-langkah analisis citra RS selanjutnya yaitu klasifikasi untuk penggolongan topologi pemukiman dan pemetaan dengan SIG. Berdasarkan peta dasar pada basis data, selanjutnya data diklasifikasi sesuai morfologi dan topologi pemukiman. Klasifikasi pemukiman menggunakan tiga kategori golongan yaitu pemukiman padat informal, pemukiman miskin informal, dan pemukiman padat formal.

Interpretasi wilayah diekstraksi menggunakan supervised maximum likelihood classification dengan lima kelas utama lahan yaitu air, tanah, vegetasi, bangunan, dan jalan. Supervised classification adalah metode pengelompokan nilai piksel berdasarkan informasi-informasi land coverage yang aktual di permukaan bumi. Pendekatan klasifikasi ini menghasilkan informasi yang lebih realistis dan akurat dibandingkan unsupervised classification yang hanya menghasilkan sekelompok cluster dan membutuhkan interpretasi lebih lanjut.

Pembuatan peta digital menggunakan software ESRI ArcGIS dan Microsoft Excel yang sekaligus membantu proses analisis data. Hasil desain peta tersimpan di basis data dalam bentuk raster. Penggunaan ragam kode warna dalam pemetaan dapat menunjukkan indikasi tingkat kemiskinan. 


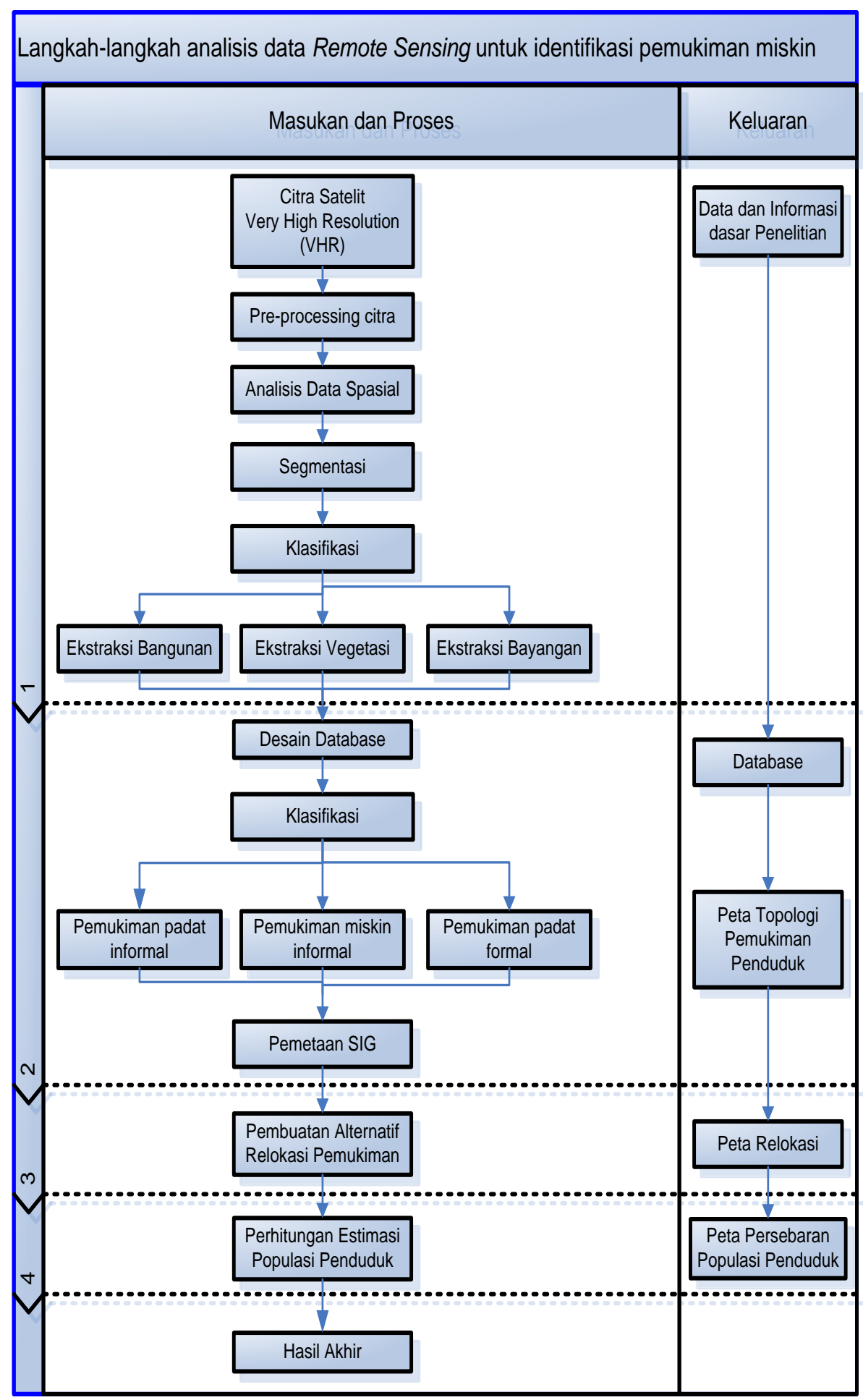

Gambar 6. Sintesa langkah-langkah analisis data RS untuk identifikasi pemukiman miskin.

Untuk wilayah dengan warna yang gelap menunjukkan tingkat kemiskinan yang tinggi. Setiap kode warna sebagai tingkat kemiskinan dicantumkan sebagai legend untuk setiap peta. Pada tahapan ini juga dilakukan penilaian tingkat akurasi dengan cara mengevaluasi dan membandingkan data kondisi sebenarnya di lapangan (ground truth) dengan peta hasil klasifikasi.Sintesa langkah-langkah analisis citra RS selanjutnya yaitu pembuatan peta alternatif 
relokasi penduduk. Peta ini merupakan hasil yang diperoleh dari analisis wilayah dan pemukiman penduduk, karena biasanya pemukiman miskin berada di dekat zona berbahaya dan rawan bencana alam. Penentuan lokasi relokasi pemukiman penduduk baru merupakan perwujudan rehabilitasi dari perkotaan yang padat. Wilayah rencana relokasi tersebut sebaiknya memiliki bahaya bencana yang kecil dengan ketersediaan akses ke sumber daya kehidupan.

Sintesa langkah-langkah analisis citra RS selanjutnya yaitu perhitungan estimasi populasi pemukiman miskin. Estimasi populasi dilaksanakan dengan menghitung building roof yang berhasil diekstraksi dikalikan dengan Roof Area per Person (RApP). RApP merupakan pembagian jumlah referensi bangunan dengan jumlah referensi populasi. Data jumlah referensi ini diperoleh dari data survei milik pemerintah. Hasil perhitungan ini akan melalui uji validitas yakni dengan membandingkan data estimasi populasi dengan data populasi sebenarnya dari BPS.

Paper ini mengusulkan metode dan alat untuk menentukan secara spasial wilayah pemukiman miskin Indonesia. Aspek penting lainnya adalah bagaimana kemiskinan dapat digambarkan dengan konsep, diukur, dan dianalisis dalam konteks yang berbeda. Dengan membandingkan wilayah pemukiman miskin dengan topologi yang diekstraksi menunjukkan fenomena yang bersifat multidimensi.

\section{Kesimpulan}

Setiap wilayah di dunia memiliki karakteristik sebaran penduduk dan penggunaan lahan yang unik serta dapat berubah dalam periode waktu tertentu. Perubahan komposisi penduduk dan pemukiman salah satu penyebab perubahan tata guna lahan dan perubahan ekosistem alam. Hal ini mendasari penelitian tentang panggunaan SIG dan RS yang menganalisis pola perubahan topologi dan morfologi lahan terutama di perkotaan. Tidak hanya itu, dengan analisis SIG dan RS juga dapat digunakan dalam perhitungan wilayah dan pemukiman penduduk miskin di perkotaan, penentuan lokasi relokasi perumahan baru sebagai rehabilitasi dari perkotaan yang padat. Wilayah relokasi tersebut sebaiknya berlokasi di luar kota dengan tingkat bahaya bencana yang kecil, ketersediaan akses ke sumber daya kehidupan.

Wilayah perkotaan dengan pemukiman penduduk yang padat dan miskin memiliki beberapa karakteristik berikut: (1) penurunan fungsi alam dengan vegetasi ruang hijau dan kualitas tanah yang berkurang, (2) penumpukan building roof pada lokasi-lokasi tertentu yang dekat dengan akses transportasi, industri dan pasar, dan (3) pemukiman dekat dengan zona berbahaya seperti dekat dengan terminal, sepanjang aliran sungai dan jalur rel.

Ada indikasi korelasi antara morfologi wilayah miskin dengan tingkat indeks kemiskinan penduduk, yakni semakin tinggi nilai indeks kemiskinan maka wilayah tersebut semakin tampak miskin secara fisik, kepadatan bangunan yang tinggi dan ruang vegetasi hijau yang rendah. Jadi, dengan teknologi RS dapat diketahui bahwa nilai indeks kemiskinan di suatu wilayah dapat dihubungkan dengan variabel wilayah yang miskin secara fisik dan vegetasi. Semakin tinggi nilai indeks kemiskinan maka wilayah tersebut semakin tampak miskin secara fisik, dengan kepadatan bangunan yang tinggi dan ruang vegetasi hijau yang rendah.

Paper ini mengisyaratkan, penelitian untuk topik analisis topologi dan estimasi penduduk pada pemukiman miskin dengan menggunakan indikator berdasarkan data RS hingga saat ini masih memiliki banyak tantangan. Tantangan utama adalah meningkatkan keakuratan dalam ekstraksi building roof yang digunakan sebagai landasan pembuatan peta sebaran pemukiman miskin. Selain itu, pengembangan analisis pemukiman miskin dengan teknologi RS dapat ditingkatkan dengan penggunaan kualitas citra VHR yang baik dan ketersediaan dataset SIG yang lengkap yang dapat mendukung pendekatan yang lebih akurat dan terintegrasi.

Pengembangan sistem SIG dan RS untuk analisis topologi dan estimasi penduduk pemukiman miskin di Indonesia sangat mungkin dilakukan. Beberapa penelitian sebelumnya telah memberikan landasan metode pengembangan. Wilayah perkotaan Indonesia juga memiliki karakteristik yang sama dengan wilayah perkotaan pada negara-negara berkembang.

Teknologi geospasial yang terintegrasi seperti RS, SIG, dan GPS dapat berkontribusi secara interaktif dalam penilaian, pemahaman dan pemetaan fasilitas layanan untuk memecahkan masalah pemukiman penduduk yang kompleks di Indonesia. Dengan menggunakan data RS dan teknik pemetaan SIG, perubahan struktur pemukiman penduduk Indonesia dapat diawasi dan dipetakan untuk proyek pengembangan yang spesifik.

\section{Referensi}

[1] UN-HABITAT, Global Urban Observatory, UN_HABITAT, 
http://ww2.unhabitat.org/programmes/guo/d efault.asp, 2003, retrieved May 17, 2010.

[2] Bappenas \& UNDP, Kita Suarakan MDGs Demi Pencapaiannya di Indonesia, Laporan Kerja Proyek MDGs, Jakarta, 2007.

[3] R. Burhani, BPS: Penduduk Miskin Indonesia Sebanyak 32,53 Juta Jiwa, Antara, http://www.antara.co.id/berita/1246449169/b ps-penduduk-miskin-indonesia-sebanyak-3253-juta-jiwa, July 1, 2009, retrieved April $10,2010$.

[4] United Nations Human Settlements Programme (UN-HABITAT), Country Programme Document 2008-2009 Indonesia, Nairobi, Kenya, 2008.

[5] R. Sliuzas \& M. Kuffer, Analysing The Spatial Heterogeneity of Poverty Using Remote Sensing: Typology of Poverty Areas Using Selected RS Based Indicators. Cartsen Jurgens (Ed.): Remote sensing - New Challenges of High Resolution, Bochum, pp. 158-167, 2008.

[6] M.C.T.M. Vicente, et,al., The Urban Poverty Morphology Project: RS-GIS Applications for Metro-Manila, Philippines. Global Spatial Infrastructure Assosiation, http://www.gsdidocs.org/gsdiconf/GSDI9/abstracts/TS55.2abstract.pdf, 2007 , retrieved March 25, 2010.

[7] M. Aminipouri, R. Sliuzas, \& M. Kuffer, "Object-Oriented Analysis Of Very High Resolution Orthophotos For Estimating The Population Of Slum Areas, Case Of DarEs-Salaam, Tanzania. ISPRS High Resolution Earh Imaging for Geospatial Information" Hannover Workshop, p. 6, 2009.

[8] M. Netzband \& A. Rahman, "Physical Characterisation of Deprivation in Cities: How Can Remote sensing Help to Profile Poverty (slum dwellers) in the megacity of Delhi/India?)" IEEE Urban Remote sensing Joint Event, pp. 1-5, 2009.

[9] C.D. Elvidge, K.E. Baugh, P.C. Sutton, \& E.H. Erwin, "Can Poverty Rates Be Estimated Using Satellite Data?" IEEE, Urban Remote sensing Joint Event, pp. 1-4, 2007. 